\title{
PENGARUH IMPLEMETASI PENGENDALIAN INTERNAL DAN KOMPETENSI PENGELOLA TERHADAP EFEKTIVITAS MANAJEMEN ASET TETAP PADA PERGURUAN TINGGI NEGERI BERBADAN HUKUM
}

\author{
SABIRIN \\ IAIN Pontianak \\ SYARBINI IKHSAN \\ Universitas Tanjungpura Pontianak
}

\begin{abstract}
This study aims to analyze the effect of the Implementation of Internal Control and Manager Competence on the Effectiveness of Fixed Asset Management in State Universities as Legal Entities partially or simultaneously. The population in this study is the Legal Entity State Universities in Indonesia, amounting to eleven. The sampling technique is saturated or census sampling. This research uses a quantitative approach with multiple regression analysis techniques. The results of the research show that the implementation of internal control and managerial competence has a significant positive effect on the effectiveness of fixed asset management, in Indonesian legal institutions both partially and simultaneously.
\end{abstract}

Key Word: Implementation of Internal Control, Manager Competence and Effectiveness of Fixed Asset Management

\section{PENDAHULUAN}

Berdasarkan Peraturan Pemerintah Republik Indonesia Nomor 4 tahun 2014 mengenai penyelenggaraan pendidikan tinggi dan pengelolaan perguruan tinggi, Perguruan Tinggi Negeri Berbadan Hukum (PTNBH) merupakan perguruan tinggi yang memiliki entitas hukum yang mandiri, transparan dan akuntabel yang memiliki otonomi dalam tata kelola organisasi dan pola pengelolaan keuangan serta memiliki kewenangan mandiri baik akademik maupun non akademik. Dalam pengelolaan keuangannya, Perguruan Tinggi Negeri Badan Hukum (PTNBH) merupakan solusi bagi perguruan tinggi negeri karena lebih fleksibel dan memberikan otonomi yang lebih besar dalam kegiatan akademik dan non akademik. Dengan adanya model pengelolaan ini, diharapkan pengelolaan perguruan tinggi negeri lebih fleksibel dan mengurangi beban operasional perguruan tinggi yang ditanggung oleh pemerintah karena fleksibilitas perolehan sumber dana oleh PTNBH.

PTNBH merupakan perguruan tinggi negeri yang sepenuhnya milik negara dan tidak dapat dialihkan kepada perseorangan atau swasta. Untuk melaksanakan fungsi pendidikan tinggi yang berada dalam lingkup tanggung jawab kementerian. Menurut Dian Puji N. Simatupang dalam workshop "UI Sebagai Perguruan Tinggi Negeri Badan Hukum (PTNBH)" menjelaskan bahwa, pada dasarnya PTNBH bersifat lebih fleksibel serta memberikan otonomi yang lebih besar dalam pengelolaan akademik dan non-akademik bagi universitas yang bersangkutan. Karena masih banyaknya permasalahan atas pengelolaan aset maka fleksibilitas ini harusnya dapat dimanfaatkan sebesar-besarnya demi kepentingan perguruan tinggi tersebut terutama dalam hal 
pengelolaan aset. (Sumber: https://www.ui.ac.id /berita/memahami-pentingnya-sistempengelolaan-aset-di-ptnbh.html)

Berikut disajikan tabel presentase perbandingan total aset dan aset tetap pada Perguruan Tinggi Negeri Berbadan Hukum.

\section{Tabel 1}

Tabel Presentase Perbandingan Aset Tetap dan Total Aset pada Perguruan Tinggi Negeri Berbadan Hukum

\begin{tabular}{|l|c|c|c|c|}
\hline \multicolumn{1}{|c|}{ Tahun } & $\mathbf{2 0 1 5}$ & $\mathbf{2 0 1 4}$ & $\mathbf{2 0 1 3}$ & $\mathbf{2 0 1 2}$ \\
\hline Institut Teknologi Sepuluh November & $78.21 \%$ & $76.52 \%$ & $82.3 \%$ & $88.97 \%$ \\
\hline Universitas Hasanuddin & $68.82 \%$ & $72.56 \%$ & $75.43 \%$ & $71.67 \%$ \\
\hline Universitas Diponegoro & $89.12 \%$ & $88.65 \%$ & $84.37 \%$ & $83.67 \%$ \\
\hline Univeristas Padjadjaran & $91.83 \%$ & $90.10 \%$ & $90.42 \%$ & $92.30 \%$ \\
\hline Universitas Airlangga & $86.23 \%$ & $83.76 \%$ & $83.99 \%$ & $81.14 \%$ \\
\hline Universitas Sumatera Utara & $78.67 \%$ & $75.42 \%$ & $74.65 \%$ & $73.54 \%$ \\
\hline Universitas Pendidikan Indonesia & $84.87 \%$ & $91.44 \%$ & $90.32 \%$ & $89.67 \%$ \\
\hline Universitas Indonesia & $83.21 \%$ & $77.63 \%$ & $80.12 \%$ & $85.05 \%$ \\
\hline Universitas Gadjah Mada & $78.81 \%$ & $83.75 \%$ & $84.94 \%$ & $82.12 \%$ \\
\hline Institut Pertanian Bogor & $86.65 \%$ & $88.45 \%$ & $85.32 \%$ & $84.54 \%$ \\
\hline Institut Teknologi Bandung & $53,33 \%$ & $52,61 \%$ & $60,14 \%$ & $64,37 \%$ \\
\hline
\end{tabular}

Sumber : Laporan keuangan perguruan tinggi, diolah

Dari tabel di atas dapat dilihat bahwa presentase total aset tetap memiliki presentase di atas limapuluh persen dalam laporan keuangan masing-masing PTNBH sehingga memiliki pengaruh signifikan dalam suatu perguruan tinggi, maka diperlukan perhatian yang lebih dalam mengelola aset tetap tersebut.

Manajemen aset merupakan sebuah proses pengelolaan aset (kekayaan) baik berwujud dan tidak berwujud yang memiliki nilai ekonomis, nilai komersial, dan nilai tukar, serta mampu mendorong tercapainya tujuan. Melalui proses management planning, organizing, leading dan controlling bertujuan mendapat keuntungan dan mengurangi biaya (cost) secara efisien dan efektif. Dalam pengelolaan suatu kekayaan diperlukan ilmu manajemen yang khusus dan spesifik mengelola kekayaan (asset). (Sumber : http://www.bppk.kemenkeu.go.id/ publikasi/artikel/149artikel-kekayaan-negara-dan-perimbangan-keuangan/20086-pentingnya-manajemen-asetnegara).

Hasil pemeriksaan terhadap penyajian dan pengungkapan aset pada PTNBH menunjukan bahwa pada PTNBH belum sepenuhnya dengan baik dilakukan sehingga menimbulkan permasalahan-permasalahan sebagai berikut:

Tabel 2

Tabel Laporan Hasil Pemeriksaan BPK terhadap penyajian dan pengungkapan Aset Pemerintah pada PTNBH Tahun 2015

\begin{tabular}{|c|l|}
\hline No & \multicolumn{1}{|c|}{ Temuan } \\
\hline 1 & $\begin{array}{l}\text { Terdapat Aset PTNBH sebesar Rp.1.298.750.299.367,00 yang belum jelas } \\
\text { perhitungannya. }\end{array}$ \\
\hline 2 & $\begin{array}{l}\text { Terdapat beberapa PTNBH yang memiliki aset belum tercatat baik pada } \\
\text { laporan, hal ini disebabkan belum lengkapnya administrasi dari perolehan aset } \\
\text { sehingga aset belum tercatat dengan benar. }\end{array}$ \\
\hline 3 & $\begin{array}{l}\text { Aset yang dikuasai atau bersengketa pada perguruan tinggi berbadan hukum } \\
\text { sebesar Rp171,56 miliar (7,23\%), pemanfaatan aset oleh pihak lain tanpa } \\
\text { dasar hukum dan atau belum dikelola optimal sebesar Rp12,13 miliar (7,23\%), } \\
\text { penggunaan langsung penerimaan atau belum disetor ke kas negara sebesar }\end{array}$ \\
\hline
\end{tabular}




\begin{tabular}{|c|l|}
\hline & $\begin{array}{l}\text { Rp65,36 miliar (14,46\%), dan penerimaan hibah yang tidak sesuai ketentuan } \\
\text { sebesar Rp2,77 miliar (8,43\%). }\end{array}$ \\
\hline 4 & $\begin{array}{l}\text { Terdapat perlakuan atas aset PTNBH pada dua Laporan Keuangan PTNBH } \\
\text { (Unair dan IPB) yang tidak dijelaskan secara memadai. }\end{array}$ \\
\hline 5 & $\begin{array}{l}\text { BPK tidak dapat meyakini saldo Investasi Permanen Lain-Lain Pemerintah } \\
\text { pada PTNBH Tahun 2015 sebesar Rp1.300.456.519.283,00 yang terdiri dari: } \\
\text { (a) Aset pada Unair sebesar Rp423.853.838.854,00 yang belum dapat } \\
\text { dipastikan apakah sudah diperhitungkan dalam perhitungan kekayaan } \\
\text { PTNBH, ing } \\
\text { (b) saldo investasi pada IPB sebesar Rp875.357.971.819,00 yang belum } \\
\text { didasarkan pada LK PTNBH yang telah diaudit, aset yang belum jelas } \\
\text { distribusinya, dan penetapan kekayaan PTNBH kurang akurat, dan }\end{array}$ \\
\hline 6 & $\begin{array}{l}\text { Temuan pada ITB dimana Terdapat kelalaian yang disebabkan oleh pengelola } \\
\text { aset yang tidak cermaqt dalam menentukan nilai sewa bangunan yang } \\
\text { mengakibatkan kerugian sebesar Rp. 30.929.604.546,- bagi perguruan tinggi } \\
\text { tersebut. }\end{array}$ \\
\hline 7 & $\begin{array}{l}\text { Temuan pada IPB dimana terdapat aset PTNBH sebesar Rp. } \\
874.896 .460 .513,00 \text { belum dapat dijelaskan distribusinya pada LK baik SAK } \\
\text { maupun SAP }\end{array}$ \\
\hline
\end{tabular}

Sumber : Laporan Hasil Pemeriksaan BPK Tahun 2015

Selain fenomena di atas, menurut data yang dinyatakan oleh Indonesia Procurement Watch (IPW) tahun 2016 menyatakan bahwa, pengadaan menjadi salah satu penyumbang terbesar tindak pidana korupsi dalam siklus manajemen aset. Kegagalan sistem tersebut mengindikasikan terdapat kelemahan dalam sistem pengawasan dan pengendalian intern. Maraknya kasus korupsi dalam proses pengadaan barang dan jasa pemerintah merupakan aktivitas pelanggaran terhadap manajemen aset di perguruan tinggi, banyak pejabat pemerintah harus berhadapan dengan hukum karena melakukan penyelewengan, dari 468 kasus korupsi yang ditangani Komisi Pemberantasan Korupsi (KPK), 70\% diantaranya merupakan kasus pengadaan barang dan jasa LKPP menyebutkan 3 (tiga) kelemahan yang ada dalam proses pengadaan barang/jasa pemerintah selama ini, yaitu: terkait transparansi, inefisiensi, dan ketidaksesuaian fungsi pengadaan. Polapola lain yang ditemukan ICW dalam perguruan tinggi yaitu Korupsi dana hibah atau CSR, korupsi anggaran internal perguruan tinggi, korupsi penjualan aset milik perguruan tinggi, dan korupsi dana Sumbangan Pembinaan Pendidikan (SPP) mahasiswa dan merugikan negara mencapai Rp. 218 miliar.

Salah satu temuan di perguruan tinggi negeri yang saat ini sudah ditangani Komisi Pemberantasan Korupsi yakni pemeriksaan lanjutan pada Universitas Indonesia yakni pada proyek gedung dan perpustakaan dengan tiga temuan BPK. Sebelumnya BPK menemukan nilai penyimpangan untuk proyek tersebut sebesar Rp9,823 miliar dengan totak kerugian negara mencapai Rp6,450 miliar.Selain itu, objek pemeriksaan BPK untuk Belanja Modal tahun 2011 dan 2012 hingga semester pertama dan Pengelolaan Aset Tetap pada Universitas Indonesia di Depok dengan 14 temuan mencapai sekitar Rp113,342 miliar dengan kerugian negara Rp43,180 miliar. (Sumber : https://www.tempo.co/topik/ masalah/109/ kasus-korupsi-di-daerah)

Selain fenomena-fenomena di atas, permasalahan dalam siklus manajemen aset adalah adanya realita di lapangan yang menunjukkan banyak kasus yang sebenarnya dimulai dari salah kelola dan salah urus masalah aset, sehingga berdampak kerugian yang tidak sedikit. Sebagai contoh optimalisasi sumber daya tidak bisa dilakukan secara maksimal karena tidak teridentifikasi dengan jelas, sehingga sulit untuk mengetahui apakah suatu alat sudah saatnya untuk diganti atau masih layak untuk di lakukan pemeliharaan. Apabila harus di lakukan pemeliharaan kapan waktu yang tepat untuk melakukan hal tersebut, dan kalau harus diganti apakah dengan jenis alat yang sama atau ada alternatif lain yang lebih baik. 
Penyebab terjadinya korupsi menurut KPMG Fraud, bribery and Corruption Survey 2013 yang dilakukan di Australia dan New Zealand tahun 2012 adalah lemahnya pengendalian intern yaitu sebesar $28 \%$ responden, faktor kedua adalah mengesampingkan sistem pengendalian intern yang telah ada yaitu sebesar 19\%. Sedangkan $42 \%$ kecurangan terdeteksi sebagian besar karena adanya pengendalian intern (KPMG, 2013). Sejalan dengan itu pengendalian intern yang efektif mengurangi kecenderungan kecurangan dalam organisasi (Zang et al : 2007). Oleh karena itu keberadaan dan pelaksanaan sistem pengendalian intern sangat penting. Menurut International Professional Practice Framework (IPPF) 2015 menjelaskan bahwa salah satu fungsi dari pengendalian internal adalah untuk pengamanan aset organisasi tersebut.

Hal senada diungkapkan dalam penelitian yang dilakukan Rendon dan Rendon (2016) menyatakan bahwa pengendalian internal berfungsi untuk mencegah dan mendeteksi penyimpangan yang terjadi dalam organisasi. Japhet (2011) menjelaskan bahwa efektivitas dan efisiensi dari pengendalian internal berkaitan dengan upaya pengamanan dan pengelolaan aset. Sedangkan menurut penelitian mengenai pengelolaan aset yang dilakukan Shabrina (2014) menyatakan bahwa sumber daya pengelola aset merupakan salah satu faktor yang mengakibatkan ketidakefektivan pelaksanaan pengelolaan aset.

Berdasarkan fakta yang dikemukankan di atas, terdapat ketidak efektivan dalam pengelolaan aset salah satunya disebabkan oleh kompetensi pengelolanya. Hal ini senadadengan pendapat yang dikemukakan (Hastings, 2010:23) yang menjelaskan bahwa dalam pengelolaan manajemen aset membutuhkan kompetensi sumber daya manusia yang sesuai dengan tugas, termasuk pengetahuan yang sesuai, keterampilan, pengalaman, perilaku, sikap, dan sifat.

Menurut penelitian yang dilakukan Diaswati Mardiasmo, et al. (2011), Manajer pengelolaan aset, harus berupaya untuk memastikan profesionalisme sumber dayanya dalam praktek manajemen aset negara. Hal senada diungkapkan oleh Mita Arlini et.al (2016) yang menyatakan bahwa, sumber daya manusia harus memiliki pengetahuan, keterampilan yang baik dalam pelaksanaan manajemen aset, akuntabilitas publik, monitoring dan evaluasi, dan efektivitas pengelolaan aset yang diselenggarakan untuk mencapai laporan aset yang baik.

Mengingatnya Pentingnya Pengendalian Internal dan Kompetensi Pengelola terhadap Efektivitas Manajemen Aset, maka peneliti tertarik melakukan penelitian tentang Pengaruh Implemetasi Pengendalian Internal dan Kompetensi Pengelola terhadap Efektivitas Manajemen Aset Tetap pada Perguruan Tinggi Negeri Berbadan Hukum.

Penelitian ini memiliki tujuan untuk mengetahui dan menganalisis pengaruh Pengendalian Internal dan Kompetensi Pengelola terhadap Efektivitas Manajemen Aset Tetap pada Perguruan Tinggi Negeri Berbadan Hukum secara parsial maupun secara simultan.

\section{TINJAUAN PUSTAKA}

\subsection{Teori Normatif}

Menurut Nelson (1973) Teori normatif menyebutkan tentang bagaimana akuntansi seharusnya dipraktekkan berdasarkan peraturan yang berlaku. Teori normatif yang berbentuk standar pelaksanaan merupakan acuan teori dalam memberikan jalan terbaik untuk meramalkan berbagai fenomena akuntansi dan menggambarkan bagaimana interaksi antar-variabel akuntansi dalam dunia nyata.

Perguruan Tinggi Negeri Berbadan Hukum merupakan Perguruan Tinggi dibawah lingkup Kementrian Riset, Teknologi dan Pendidikan Tinggi yang wajib melakukan pengendalian atas penyelenggaraan kegiatan pemerintahan dalam hal pengelolaan aset dengan berpedoman pada SPIP yaitu Peraturan Pemerintah Nomor 60 Tahun 2008 tentang Sistem Pengendalian Intern Pemerintah dengan tujuan pengendalian internal untuk mencapai efektivitas dan efisiensi pencapaian tujuan pemerintahan, keandalan laporan keuangan, pengamanan aset negara dan ketaatan terhadap peraturan perundang-undangan.( Jamal Wiwoho, 2017). 


\subsection{Teori Organisasi}

Menurut Lubis dah Husein (1987) Teori organisasi berhubungan dengan kinerja dalam sebuah organisasi. Salah satu kajian teori organisasi, diantaranya membahas tentang bagaimana sebuah organisasi menjalankan fungsi dan mengaktualisasikan visi dan misi organisasi tersebut. Selain itu, dipelajari bagaimana sebuah organisasi mempengaruhi dan dipengaruhi oleh orang didalamnya maupun lingkungan kerja organisasi tersebut.

Dalam penelitian ini kompetensi pengelola aset dijelaskan dengan teori organisasi dimana dalam teori organisasi memandang organisasi sebagai kumpulan orang yang terlibat pada kegiatan-kegiatan terbuka dan partisitipasif untuk mencapai tujuan instansi. Teori organisasi berorientasi menganggap bahwa dalam menghadapi manusia, manajemen harus memperlakukan mereka sebagai elemen pasif yang harus diarahkan, dimotivasi, diawasi, dan dimodifikasi agar sesuai dengan kebutuhan organisasi yaitu dalam hal pengelolaan aset.

\subsection{Kerangka Berpikir dan Pengembangan Hipotesis} Pengaruh Implementasi Pengendalian Internal terhadap Efektivitas Manajemen Aset

Indra Bastian (2014) menyatakan bahwa pengendalian internal membantu organisasi mencapai tujuannya melalui pendekatan yang sistematik yang dapat dilakukan oleh instansi agar tercipta suatu bentuk pengendalian yang optimal dalam mencegah serta menanggulangi kecurangan-kecurangan yang mungkin terjadi di instansi serta dapat mengetahui dan meminimalisir risiko-risiko yang akan dihadapi dalam pengelolaan aset, dengan demikian hal ini juga akan meningkatkan efisiensi dan efektivitas dari kegiatan operasional instansi, termasuk didalamnya adalah efektivitas manajemen asset.

Hal senada dikemukakan oleh The Australian Aset Management Collaborative Group's - AAMCoG dalam Pengelolaan Aset yang Strategis (Integrated Strategic Asset Management ISAM) menjelaskan bahwa Setiap organisasi perlu meninjau kinerja aset dan sistem pengelolaan aset secara rutin, untuk memastikan bahwa kinerja tersebut sejalan dengan objektif pengelolaan aset dan kebutuhan pengadaan pelayanan. Pengendalian internal aset tetap dalam suatu organisasi sektor publik merupakan bagian penting dan harus menjadi fokus pengawasan, pengawasan dalam pengendalian internal merupakan cara yang efisien untuk memastikan kebijakan manajemen dalam menjaga aset (Japhet, 2011).

Hal senada diungkapkan penelitian yang dilakukan Rendon dan Rendon (2016) yang menyatakan bahwa pengendalian internal berfungsi untuk mencegah dan mendeteksi penyimpangan yang terjadi dalam organisasi. Japhet (2011) menyatakan bahwa Efektivitas dan efisiensi dari pengendalian internal berkaitan dengan upaya pengamanan dan pengelolaan aset.

Berdasarkan penjelasan di atas, hipotesis yang diajukan yaitu :

$\mathrm{H}_{1}$ : Pengendalian internal berpengaruh positif dan signifikan terhadap manajemen aset

\subsection{Pengaruh Kompetensi Pengelola terhadap Efektivitas Manajemen Aset}

Menurut Hastings (2010) pengelolaan manajemen aset membutuhkan kompetensi sumber daya manusia yang sesuai dengan tugas, termasuk pengetahuan yang sesuai, keterampilan, pengalaman, perilaku, sikap, dan sifat. Menurut penelitian yang dilakukan Diaswati Mardiasmo, et al. (2011) manajer pengelolaan aset harus berupaya untuk memastikan profesionalisme sumber dayanya dalam praktek manajemen aset. Hal senada diungkapkan oleh Peach (2014) yang menyatakan bahwa "Human resources should have knowledge, good skills by taking into account the relationships among the implementation of asset management, public accountability, monitoring and evaluation, and the effectiveness of the local asset management which is organized to achieve a good asset reports."

Berdasarkan penelitian yang dilakukan Peach (2014) di University of Queensland Knowledge dan skill staff meningkat semenjak diberlakukan sistem baru dalam pengelolaan manajemen aset. Hal ini senada dengan penelitian yang dilakukan Mita Arlini et.al (2016) yang 
menyatakan bahwa, sumber daya manusia harus memiliki pengetahuan, keterampilan yang baik dalam pelaksanaan manajemen aset, akuntabilitas publik, monitoring dan evaluasi, dan efektivitas pengelolaan aset yang diselenggarakan untuk mencapai laporan aset yang baik. Penelitian yang dilakukan Grubisic (2009), Efektivitas Manajemen Aset Publik diukur dari klasifikasi aset publik, pengakuan aset publik, pengukuran aset publik dan profesionalisme dalam pengelolaan aset publik

Klett (2011) juga merekomendasikan perlunya pelatihan secara berkesinambungan demi pengembangan sumber daya manusia guna menambah knowledge dan skill bagi para pengelola aset dan kompetensi sumber daya manusia merupakan kemampuan untuk melaksanakan fungsifungsi untuk mencapai tujuannya secara efektif dan efisien.Berdasarkan penjelasan di atas, hipotesis yang diajukan yaitu :

$\mathrm{H}_{2}$ : Kompetensi pengelola berpengaruh positif dan signifikan terhadap manajemen aset.

Kerangka pemikiran yang telah diuraikan oleh penulis di atas dapat dilihat pada gambar kerangka konseptual penelitian dibawah ini :

\section{Gambar 1}

\section{Kerangka Konseptual Penelitian}

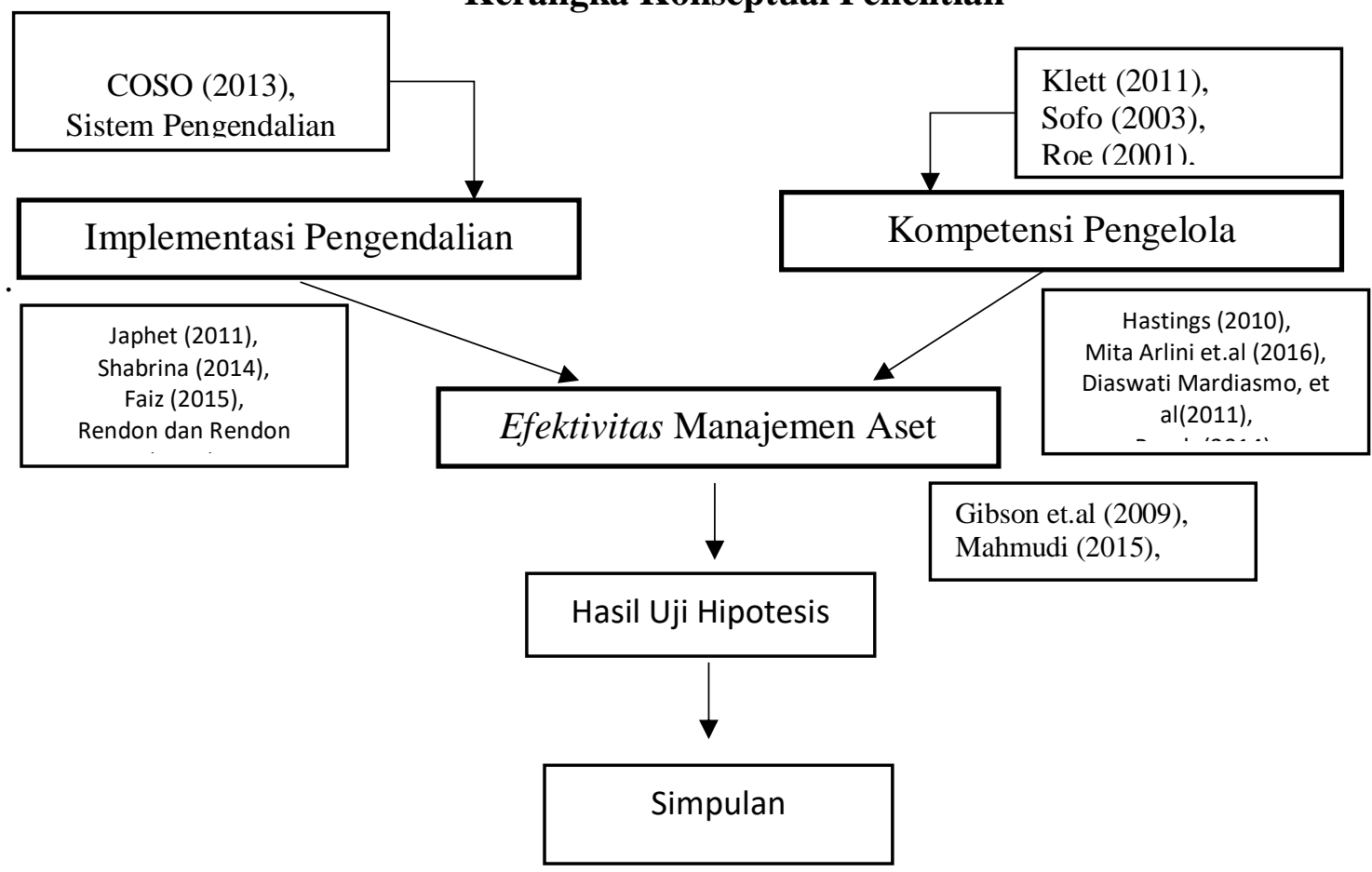

\section{METODOLOGI PENELITIAN}

\subsection{Unit Analisis, Populasi dan Sampel Penelitian}

unit analisis dalam penelitian ini adalah Perguruan Tinggi Negeri Berbadan Hukum di Indonesia. Populasi dalam penelitian ini adalah Perguruan Tinggi Negeri Berbadan Hukum di Indonesia. Adapun Perguruan Tinggi Negeri Berbadan Hukum di Indonesia berjumlah 11 (sebelas) diantaranya: Institut Teknologi Bandung, Universitas Gadjah Mada, Institut Pertanian Bogor, Universitas Indonesia, Universitas Pendidikan Indonesia, Universitas Sumatera Utara, Universitas Airlangga, Universitas Padjadjaran, Universitas Diponegoro, Universitas Hasanuddin, Institut Teknologi Sepuluh Nopember.

Teknik pengambilan sampel adalah dengan sampling jenuh atau sensus yaitu teknik penentuan sampel bila semua anggota populasi digunakan sebagai sampel apabila populasi relatif kecil yaitu kurang dari 30. (Sugiyono, 2013)

\subsection{Metode Pengumpulan dan Analisis Data}


Metode pengumpulan data pada penelitian ini adalah kuesioner yang merupakan teknik pengumpulan data yang dilakukan dengan cara memberikan seperangkat pertanyaan atau pernyataan tertulis kepada responden untuk dijawabnya (Sugiyono, 2013:142). Tujuan pengumpulan data dengan kuesioner dalam penelitian ini adalah untuk mengumpulkan informasi dari responden dalam penelitian ini yaitu :

1. Variabel Implementasi Pengendalian Internal (X1) dan Efektivitas Manajemen Aset (Y)

: Auditor Internal Satuan Pengawas Intenal yang mengaudit aset tetap pada Perguruan

Tinggi Negeri Berbadan Hukum.

2. Variabel Kompetensi pengelola (X2) : Para pengelola aset pada Perguruan Tinggi Negeri Berbadan Hukum.

Data yang sudah terkumpul sebelum diolah lebih lanjut akan dilakukan uji analisis terhadap instrumen atau kuesioner tersebut yaitu dengan melakukan uji validitas untuk mengukur sah atau valid tidaknya suatu kuesioner dikatan valid apabila hasil perhitungan koefisien korealasi menunjukan koefisien korelasi sebesar 0,3 atau lebih Sugiyono (2013). Selain itu juga akan dilakukan uji reliabilitas untuk mengukur suatu kuesioner yang merupakan indikator dari variabel atau kostruk. Untuk mengukur indikator tersebut digunakan Cronbach's Alpha dari masingmasing variabel. Imam Ghozali (2013:47) menyatakan bahwa suatu konstruk atau variabel dikatakan reliabel jika memberikan nilai Construct Reliability 0,70 .

\subsection{Rancangan Analisis Data dan Uji Hipotesis}

Alat untuk mengolah data dalam penelitian ini adalah SPSS (Statistikal Package for Social Science) versi 23, yaitu menggunakan Analisis Regresi Linear Berganda. Untuk melihat bagaimana pengaruh dari variabel bebas (independent) terhadap variabel terikat (dependent) dalam penelitian ini. Analisis regresi linier berganda pada dasrnya adalah analisa mengenai ketergantungan variabel dependen dengan satu atau lebih variabel independen, dengan tujuan untuk mengestimasi dan/atau memprediksi rata-rata populasi atau nilai rata-rata variabel dependen berdasarkan variabel independen yang diketahui (Ghozali, 2013:85). Analisis regresi linear berganda digunakan untuk mengukur pengaruh lebih dari satu variabel bebas terhadap variabel terikat. Rumus:

$$
\mathrm{Y}=\mathrm{a}+\beta \mathrm{X} 1+\beta \mathrm{X} 2+e
$$

Keterangan:

$\mathrm{Y}=$ Efektivitas Manajeman Aset

$\mathrm{a}=$ Konstanta

$\beta=$ Koefisien Regresi

$\mathrm{X} 1=$ Implementasi Pengendalian Internal

$\mathrm{X} 2$ = Kompetensi Pengelola

$e=$ error

\subsection{Pengujian Asumsi Klasik}

Penelitian ini melakukan tiga pengujian asumsi klasi yaitu uji normalitas,, uji heterokedastistas, dan uji multikolonieritas. Uji normalitas pada penelitian ini meggunakan pendekatan statistik uji kolomorgorov - smirnov test. Dalam hal ini untuk mengetahui apakah residual berdistribusi normal jika nilai signifikansi lebih dari 0,05. Sementara itu uji heterokedastistas dilakukan dengan uji Scatterplot, untuk mengetahui tidak terjadninya heterokedastistas yaitu dengan melihat pola. Jika tidak ada pola yang jelas, serta titik-titik menyebar diatas dan dibawah angka 0 pada sumbu Y, maka tidak terjadi heteroskedastisitas. Uji Multikolonieritas dilakukan bertujuan untuk menguji apakah model regresi ditemukan adanya korelasi antar variabel bebas (indepeden). Untuk mengetahui adanya multikolinearitas dengan melihat nilai variance inflation factor (VIF). Nilai Cutoff yang umum digunakan adalah nilai tolerance 0,10 atau sama dengan VIF diatas 10 . Apabila nilai tolerance lebih dari 0,10 atau sama dengan VIF kurang dari 10 maka dapat dikatakan bahwa tidak terjadi multikolonieritas antar variabel dalam model regresi (Imam Ghozali, 2013:105)

\subsection{Pengujian Hipotesis}




\section{Pengujian Koefisien Determinasi}

Koefisien Determinasi $\left(\mathrm{R}^{2}\right)$ pada intinya mengukur seberapa jauh kemampuan model dalam menerangkan variasi variable dependen. Nilai koefisien determinasi adalah nol dan satu. Nilai $\mathrm{R}^{2}$ yang kecil berarti kemampuan variabel-variabel independen dalam menjelaskan variasi variabel dependen amat terbatas.

\subsection{Rancangan Pengujian Hipotesis Partial (uji statistik t)}

Uji parsial digunakan untuk mengetahui pengaruh masing-masing variabel independen terhadap variabel dependen (Imam Ghozali, 2013). Kriterianya adalah apabila hasil uji menunjukkan tingkat signifikansi kurang dari 0,05 maka terdapat pengaruh yang signifikan antara satu variabel independen terhadap variabel dependen. Sebaliknya, apabila tingkat signifikansi lebih dari 0,05 maka tidak terdapat pengaruh yang signifikan antara satu variabel independen terhadap variabel dependen.

\subsection{Rancangan Pengujian Hipotesis Simultan (uji statistik F)}

Uji-F untuk menguji secara bersama-sama serempak antara variabel bebas terhadap variabel terikatnya. Uji statistik F pada dasarnya menunjukan apakah semua variabel independen atau bebas yang dimasukkan dalam model mempunyai pengaruh secara bersama-sama terhadap variabel dependen (Imam Ghozali:2013). Berikut pengambilan keputusan : Apabila F hitung > F tabel atau probabilitas < taraf signifikansi 5\% atau 0,05; artinya ada pengaruh positif yang signifikan antara semua variabel bebas secara bersama-sama terhadap efektivitas manajemen aset. Sebaliknya apabila $\mathrm{F}$ hitung $<\mathrm{F}$ tabel atau probabilitas > taraf signifikansi 5\% atau 0,05 ; artinya tidak ada pengaruh positif yang signifikan antara semua variabel bebas secara bersama-sama terhadap efektivitas manajemen aset.

\section{HASIL DAN PEMBAHASAN}

\subsection{Uji Validitas}

Bagian ini akan menyajikan hasil penelitian atas pengaruh Pengaruh Implementasi Pengdalian Internal, dan Kompetensi Pengelola Terhadap Efektivitas Manajemen Aset Tetap pada Perguruan Tinggi Negeri Berbadan Hukum baik secara parsial maupun secara simultan. Masing-masing variabel mengggunakan skala ordinal dengan rentang 1 (satu) sampai dengan 5 (lima). Data atas tanggapan responden akan diolah dengan uji statistik menggunakan software SPSS versi 23.

Teknik pengambilan sampel adalah dengan sampling jenuh atau sensus. Sampel terpilih dalam penelitian ini adalah sebanyak 202 responden. Telah dilakukan analisis terhadap kuesioner yang kembali dan dari kuesioner tersebut yang layak untuk dianalisi sejumlah 69 kuesioner sehingga jumlah seluruh sampel adalah 69 responden. Sebelum dilakukan analisis telah dilakukan uji instrumen yaitu validitas dan reabilitas serta uji asumsi klasik terhadap data primer yang diperoleh. Adapaun pengujian seperti yang dijelaskan dibawah ini :

Tabel 3

Hasil Perhitungan Validitas Variabel

\begin{tabular}{|c|c|c|c|}
\hline Variabel & Korelasi & Nilai Batas & Kesimpulan \\
\hline \multirow{4}{*}{} & 0,579 & 0,3 & Valid \\
\cline { 2 - 4 } & 0,570 & 0,3 & Valid \\
\cline { 2 - 4 } & 0,585 & 0,3 & Valid \\
\cline { 2 - 4 } & 0,713 & 0,3 & Valid \\
\cline { 2 - 4 } & 0,592 & 0,3 & Valid \\
\cline { 2 - 4 } & 0,677 & 0,3 & Valid \\
\cline { 2 - 4 } & 0,872 & 0,3 & Valid \\
\cline { 2 - 4 } & 0,872 & 0,3 & Valid \\
\cline { 2 - 4 } & 0,361 & 0,3 & Valid \\
\hline
\end{tabular}


JAAKFE

Vol.10, No.2 Des 2020, hal 25-43

Sabirin, Syarbini Ikhsan

\begin{tabular}{|c|c|c|c|}
\hline \multirow{26}{*}{$\begin{array}{c}\text { Implementasi } \\
\text { Pengendalian Internal } \\
\text { (X1) }\end{array}$} & 0,860 & 0,3 & Valid \\
\hline & 0,834 & 0,3 & Valid \\
\hline & 0,855 & 0,3 & Valid \\
\hline & 0,834 & 0,3 & Valid \\
\hline & 0,834 & 0,3 & Valid \\
\hline & 0,859 & 0,3 & Valid \\
\hline & 0,597 & 0,3 & Valid \\
\hline & 0,691 & 0,3 & Valid \\
\hline & 0,690 & 0,3 & Valid \\
\hline & 0,784 & 0,3 & Valid \\
\hline & 0,611 & 0,3 & Valid \\
\hline & 0,356 & 0,3 & Valid \\
\hline & 0,860 & 0,3 & Valid \\
\hline & 0,611 & 0,3 & Valid \\
\hline & 0,416 & 0,3 & Valid \\
\hline & 0,607 & 0,3 & Valid \\
\hline & 0,414 & 0,3 & Valid \\
\hline & 0,570 & 0,3 & Valid \\
\hline & 0,414 & 0,3 & Valid \\
\hline & 0,737 & 0,3 & Valid \\
\hline & 0,547 & 0,3 & Valid \\
\hline & 0,732 & 0,3 & Valid \\
\hline & 0,567 & 0,3 & Valid \\
\hline & 0,566 & 0,3 & Valid \\
\hline & 0,563 & 0,3 & Valid \\
\hline & 0,563 & 0,3 & Valid \\
\hline \multirow{28}{*}{$\begin{array}{c}\text { Kompetensi } \\
\text { Pengelola (X2) }\end{array}$} & 0,649 & 0,3 & Valid \\
\hline & 0,712 & 0,3 & Valid \\
\hline & 0,860 & 0,3 & Valid \\
\hline & 0,823 & 0,3 & Valid \\
\hline & 0,649 & 0,3 & Valid \\
\hline & 0,691 & 0,3 & Valid \\
\hline & 0,773 & 0,3 & Valid \\
\hline & 0,573 & 0,3 & Valid \\
\hline & 0,518 & 0,3 & Valid \\
\hline & 0,668 & 0,3 & Valid \\
\hline & 0,676 & 0,3 & Valid \\
\hline & 0,571 & 0,3 & Valid \\
\hline & 0,794 & 0,3 & Valid \\
\hline & 0,539 & 0,3 & Valid \\
\hline & 0,573 & 0,3 & Valid \\
\hline & 0,406 & 0,3 & Valid \\
\hline & 0,562 & 0,3 & Valid \\
\hline & 0,754 & 0,3 & Valid \\
\hline & 0,541 & 0,3 & Valid \\
\hline & 0,726 & 0,3 & Valid \\
\hline & 0,406 & 0,3 & Valid \\
\hline & 0,394 & 0,3 & Valid \\
\hline & 0,380 & 0,3 & Valid \\
\hline & 0,743 & 0,3 & Valid \\
\hline & 0,735 & 0,3 & Valid \\
\hline & 0,557 & 0,3 & Valid \\
\hline & 0,816 & 0,3 & Valid \\
\hline & 0,797 & 0,3 & Valid \\
\hline
\end{tabular}




\begin{tabular}{|c|c|c|c|}
\hline \multirow{4}{*}{$\begin{array}{c}\text { Efektivitas } \\
\text { Manajemen Aset } \\
\text { Tetap (Y) }\end{array}$} & 0,609 & 0,3 & Valid \\
\cline { 2 - 4 } & 0,543 & 0,3 & Valid \\
\cline { 2 - 4 } & 0,824 & 0,3 & Valid \\
\cline { 2 - 4 } & 0,355 & 0,3 & Valid \\
\cline { 2 - 4 } & 0,359 & 0,3 & Valid \\
\cline { 2 - 4 } & 0,784 & 0,3 & Valid \\
\cline { 2 - 4 } & 0,717 & 0,3 & Valid \\
\cline { 2 - 4 } & 0,700 & 0,3 & Valid \\
\cline { 2 - 4 } & 0,689 & 0,3 & Valid \\
\cline { 2 - 4 } & 0,786 & 0,3 & Valid \\
\hline
\end{tabular}

\section{Sumber : SPSS 23, data diolah}

Hasil pengujian valitas item kuesioner menunjukkan bahwa seluruh item pernyataan dalam setiap Variabel memiliki nilai korelasi di atas 0,3 sebagai nilai batas suatu item kuesioner penelitian dikatakan dapat digunakan (dapat diterima). Sehingga dapat dikatakan bahwa item angket Variabel valid dan dapat digunakan untuk mengukur variabel yang diteliti.

\subsection{Uji Realibilitas}

Sementara itu Pengujian reliabilitas dalam penelitian ini adalah dengan menggunakan Cronbach's Alpha dari masing-masing variabel. Imam Ghozali (2016:47) menyatakan bahwa suatu konstruk atau variabel dikatakan reliabel jika memberikan lebih dari nilai Construct Reliability 0,70. Berikut ini akan disajikan ringkasan uji realibilitas untuk semua variabel

\section{Tabel 4}

Hasil Uji Reabilitas

\begin{tabular}{|c|c|c|}
\hline Alpha & N Of Items & Keterangan \\
\hline 0,975 & 75 & Reliabel \\
\hline
\end{tabular}

Sumber : SPSS 23, data diolah.

Berdasarkan hasil uji reliabilitas diperoleh hasil perhitungan menunjukkan nilai Cronbach's Alpha sebesar 0,975 lebih besar dari 0,730. Artinya data yang dipergunakan dalam penelitian ini reliabel atau dapat dipercaya sehingga dapat dilanjutkan pada analisis berikutnya.

\subsection{Pengujian Asumsi Klasik}

Sebelum dilakukan pembentukan model regresi, maka dilakukan pengujian asumsi terlebih dahulu supaya model yang terbentuk memberikan estimasi yang BLUE (Best Linier Unbiased Estimated). Penelitian ini melakukan pengujian asumsi terhadap 3 pengujian yaitu uji normalitas, uji heteroskedastisitas, dan uji multikolinieritas. Hasil uji akan dijelaskan sebagai berikut :

1. Uji Normalitas

Berikut ini akan disajikan perhitungan yang menunjukkan pengujian nor malitas. Dengan bantuan software SPSS Statistics diperoleh hasil uji Kolmogorov Smirnov sebagai berikut:

\section{Tabel 5}

Hasil Uji Normalitas dengan Uji One Sample Kolmogorov-Smirnov

\begin{tabular}{|c|c|}
\hline $\mathrm{N}$ & 69 \\
\hline Asymp. Sig. (2-tailed) & 0,200 \\
\hline
\end{tabular}

Sumber : SPSS 23, data diolah

Dari tabel diatas terlihat bahwa nilai Asymp. Sig yang dihasilkan dari KolmogorovSmirnov Test bernilai sebesar 0,200 yang berarti berada di atas batas maksimum error yaitu 0,05 atau probabilitas > 0,05 sehingga dapat disimpulkan bahwa data di atas memiliki residu berdistribusi normal dan dapat digunakan dalam penelitian.

2. Uji Heterokedastisitas 
Berikut ini akan disajikan perhitungan yang menunjukkan pengujian heterokedastisitas.

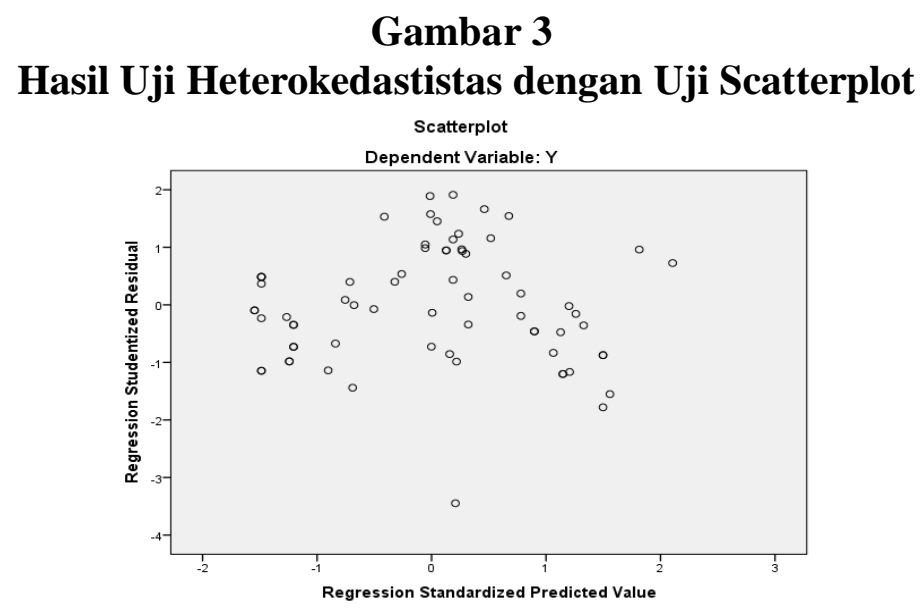

Sumber : SPSS 23, data diolah.

Dari gambar di atas dapat dilihat bahwa data yang tergambar sebagai titik-titik menyebar dan tidak membentuk pola tertentu. Selain itu titik-titik tersebut juga menyebar di atas dan di bawah angka 0 pada sumbu Y sehingga scatterplot tersebut mengindikasikan tidak terdapat heteroskedastisitas pada data yang digunakan, sehingga data dapat digunakan dalam penelitian.

3. Uji Multikolinieritas

Berikut ini akan disajikan perhitungan yang menunjukkan pengujian multikolinieritas.

Tabel 6

Ringkasan Hasil Uji Multikolinieritas

\begin{tabular}{|l|l|l|}
\hline Variabel & Tolerance & VIF \\
\hline $\mathrm{X} 1$ & 0,084 & 1,956 \\
\hline $\mathrm{X} 2$ & 0,084 & 1,956 \\
\hline
\end{tabular}

Sumber :SPSS 23, data diolah

Dari output di atas terlihat bahwa semua variabel independen memiliki tolerance value atau nilai tolerasi kurang dari 1 dan VIF kurang dari 10. Hal ini menunjukkan bahwa tidak terdapat multikolinieritas diantara variabel-variabel independen sehingga data yang diperoleh dapat digunakan dalam penelitian.

\subsection{Pengujian Metode Persamaan Regresi}

Analisis regresi digunakan untuk mengetahui kekuatan hubungan dari variabel bebas (independent) terhadap variabel terikat (dependent). Hasil pengolahan software SPSS Statistics untuk analisis regresi berganda disajikan pada tabel berikut:

Tabel 7 Hasil Output Regresi Berganda

\begin{tabular}{|c|c|c|c|}
\hline \multirow{2}{*}{ Model } & \begin{tabular}{c} 
Standardized \\
Coefficients \\
\cline { 2 - 3 }
\end{tabular} & Beta & Sig. \\
\hline Constant & 1,658 & 0,756 & 0,452 \\
\hline $\mathrm{X} 1$ & 0,574 & 3,323 & 0,024 \\
\hline $\mathrm{X} 2$ & 0,349 & 2,019 & 0,048 \\
\hline
\end{tabular}

Sumber : SPSS 23, data diolah 
Berdasarkan hasil perhitungan pada tabel diatas diperoleh bentuk persamaan regresi linier berganda sebagai berikut:

$$
\mathrm{Y}=1,658+0,574 \mathrm{X} 1+0,349 \mathrm{X} 2+e
$$

Dari persamaan regresi linier berganda di atas maka dapat dianalisis sebagai berikut:

a. Koefisien regresi Implementasi Pengendalian Internal sebesar 0,574 menyatakan bahwa setiap penambahan Implementasi Pengendalian Internal sebesar 1 satuan, maka akan meningkatkan Efektivitas Manajemen Aset Tetap sebesar 0,574.

b. Koefisien regresi Kompetensi Pengelola sebesar 0,349 menyatakan bahwa setiap penambahan Kompetensi Pengelola sebesar 1 satuan, maka akan meningkatkan Efektivitas Manajemen Aset Tetap sebesar 0,349.

\section{Analisis Koefisien Determinasi}

Dalam suatu penelitian sering ingin diketahui seberapa beesar hubungan atau pengaruh antara variabel-variabel bebas dengan variabel terikat seperti yang dapat dilihat dari koefisien determinasi pada tabel di bawah ini:

Tabel 8

Koefisien Determinasi

\begin{tabular}{|c|c|c|c|c|}
\hline Model & $\mathrm{R}$ & $\mathrm{R}$ Square & $\begin{array}{c}\text { Adjusted R } \\
\text { Square }\end{array}$ & $\begin{array}{c}\text { Std. Error of the } \\
\text { Estimate }\end{array}$ \\
\hline 1 & 0,914 & 0,835 & 0,830 & 4,34651 \\
\hline
\end{tabular}

Sumber : SPSS 23, data diolah

Tabel diatas menunjukkan bahwa nilai koefisian determinasi atau Adjusted $\mathrm{R}^{2}$ bernilai sebesar 0,830 atau $83, \%$. Hal ini menunjukkaan bahwa variabel bebas secara bersama-sama mempengaruhi variabel terikat sebesar $83 \%$. Pengaruh variabel bebas tersebut sebesar $83 \%$ dapat dikatakan bersifat besar terhadap variabel terikat, sedangkan sisanya $17 \%$ dapat dijelaskan oleh variabel lain di luar model regresi di atas.

\subsection{Analisis Uji F}

Uji $\mathrm{F}$ digunakan dalam menguji koefisien regresi secara keseluruhan untuk mengetahui pengaruh antara variabel $\mathrm{X}$ secara simultan terhadap $\mathrm{Y}$. Ringkasan hasil pengujian hipotesis disajikan pada tabel berikut:

Tabel 9

Ringkasan Hasil Uji F Regresi Linear Berganda

\begin{tabular}{|c|c|c|c|}
\hline Model & Mean Square & F & Sig \\
\hline Regression & 3157,509 & 167,133 & 0,000 \\
\hline
\end{tabular}

\section{Sumber : SPSS 23, data diolah}

Dari tabel diatas diperoleh nilai signifikansi $F$ sebesar 0,000 dan nilai $F_{\text {hitung }}$ sebesar 167,133 sedangkan $F_{\text {tabel }}$ sebesar 2,744. Dengan nilai signifikansi yang lebih kecil dari 0,05 dan nilai $\mathrm{F}_{\text {hitung }}$ lebih besar dari $\mathrm{F}_{\text {tabel }}$ maka dapat disimpulkan bahwa hipotesis $\mathrm{H}_{\mathrm{o}}$ ditolak, yang berarti pada tingkat signifikansi sebesar 5\% terdapat pengaruh yang signifikan secara simultan dari variabel Implementasi Pengendalian Internal (X1), dan Kompetensi Pengelola (X2). Sehingga dapat disimpulkan bahwa semua variabel $\mathrm{X}$ bersama-sama mampu memberikan pengaruh yang signifikan terhadap terhadap Efektivitas Manajemen Aset Tetap.

\subsection{Analisis Uji T}

Pengujian secara parsial dilakukan untuk mengetahui pengaruh salah satu variabel bebas terhadap variabel terikat dengan asumsi variabel lainnya konstan. Hasil pengolahan data melalui software SPSS Statistics disajikan pada tabel berikut:

Tabel 10

\section{Ringkasan Hasil Uji t Regresi Linear Berganda}




\begin{tabular}{|c|c|c|c|}
\hline Model & $\begin{array}{c}\text { Unstandardized } \\
\text { Coefficients }\end{array}$ & $\mathrm{T}$ & $\mathrm{Sig}$ \\
\hline Constant & 1,658 & 0,756 & 0,452 \\
\hline $\mathrm{X} 1$ & 0,361 & 3,323 & 0,001 \\
\hline $\mathrm{X} 2$ & 0,345 & 2,019 & 0,048 \\
\hline
\end{tabular}

Sumber : SPSS 23, data diolah

Dengan df $=\mathrm{n}-\mathrm{k}-1=69-2-1=67$, maka diperoleh $\mathrm{t}_{\text {tabel }}$ sebesar 1.9949. Dari tabel diatas diketahui untuk variabel Implementasi Pengedalian Internal (X1) memiliki $t_{\text {hitung }}$ sebesar 3,323 apabila dibandingkan dengan $t_{\text {tabel }} 1.9949$ maka diperoleh $t_{\text {hitung }}>t_{\text {tabel }}=3,323>1.9949$. Sementara itu nilai signifikansi Implementasi Pengedalian Internal adalah 0,001 apabila dibandingkan dengan $\alpha=5 \%$ maka diperoleh $0,001<0,05$. Dengan demikian $\mathrm{H}_{\mathrm{o} 1}$ ditolak, ini berarti secara parsial Implementasi Pengedalian Internal mempunyai pengaruh yang signifikan terhadap Efektivitas Manajemen Aset Tetap. Oleh karena itu semakin tinggi Implementasi Pengedalian Internal maka akan semakin tinggi Efektivitas Manajemen Aset Tetap.

Kompetensi Pengelola (X2) diketahui memiliki nilai $t_{\text {hitung }}$ sebesar 2,019 apabila dibandingkan dengan nilai $t_{\text {tabel }} 1.9949$ maka diperoleh $t_{\text {hitung }}>t_{\text {tabel }}=2,019>1.9949$. Sementara itu nilai signifikansi Kompetensi Pengelola (X2) adalah 0,048 apabila dibandingkan dengan $\alpha=5 \%$ maka diperoleh $0,048<0,05$. Dengan demikian $\mathrm{H}_{\mathrm{o} 2}$ ditolak, ini berarti secara parsial Kompetensi Pengelola mempunyai pengaruh yang signifikan terhadap Efektivitas Manajemen Aset Tetap. Oleh karena itu semakin tinggi Kompetensi Pengelola maka akan semakin tinggi Efektivitas Manajemen Aset Tetap.

\subsection{Pembahasan}

\subsubsection{Pengaruh Implementasi Pengendalian Internal Terhadap Efektivitas Manajemen Aset Tetap Pada Perguruan Tinggi Negeri Berbadan Hukum}

Berdasarkan hasil uji statistik dapat disimpulkan bahwa Implementasi Pengedalian Internal berpengaruh positif dan siginifikan terhadap Efektivitas Manajemen Aset Tetap, yang artinya semakin baik Implementasi Pengedalian Internal maka akan semakin baik pula Efektivitas Manajemen Aset Tetap. Pengendalian internal membantu organisasi mencapai tujuannya melalui pendekatan yang sistematik yang dapat dilakukan oleh instansi agar tercipta suatu bentuk pengendalian yang optimal dalam mencegah serta menanggulangi kecurangankecurangan yang mungkin terjadi di instansi serta dapat mengetahui dan meminimalisir risikorisiko yang akan dihadapi dalam pengelolaan aset, dengan demikian hal ini juga akan meningkatkan efisiensi dan efektivitas dari kegiatan operasional instansi, termasuk didalamnya adalah efektivitas manajemen asset. Oleh karena itu, Implementasi Pengedalian Internal berpengaruh positif dan siginifikan terhadap Efektivitas Manajemen Aset Tetap, pada perguruan tinggi berbadan hukum di Indonesia.

Hasil penelitin ini senada dengan penelitian sebelumnya yang mengatakan bahwa Implementasi Pengedalian Internal berpengaruh positif dan siginifikan terhadap Efektivitas Manajemen Aset Tetap. Hal tersebut dikemukakan oleh Peach (2013) dalam penelitiannya membuktikan bahwa Kompetensi Pengelola, Knowledge dan skill staff meningkat semenjak diberlakukan sistem baru dalam pengelolaan manajemen aset. Selain itu Faiz (2015), dengan penelitiannya yang berjudul "Evaluasi implementasi sistem pengendalian internal : Studi kasus pada perguruan tinggi negeri" membuktikan bahwa Elemen pengendalian internal dalam COSO cukup efektif dalam kegiatan manajemen universitas.

Hal senada dikemukakan oleh The Australian Aset Management Collaborative Group's - AAMCoG dalam Pengelolaan Aset yang Strategis (Integrated Strategic Asset Management ISAM) menjelaskan bahwa Setiap organisasi perlu meninjau kinerja aset dan sistem pengelolaan aset secara rutin, untuk memastikan bahwa kinerja tersebut sejalan dengan objektif pengelolaan aset dan kebutuhan pengadaan pelayanan. Pengendalian internal aset tetap dalam suatu organisasi 
sektor publik merupakan bagian penting dan harus menjadi fokus pengawasan, pengawasan dalam pengendalian internal merupakan cara yang efisien untuk memastikan kebijakan manajemen dalam menjaga aset (Japhet, 2011).

Rendon dan Rendon (2016) yang menyatakan bahwa pengendalian internal berfungsi untuk mencegah dan mendeteksi penyimpangan yang terjadi dalam organisasi. Japhet (2011) menyatakan bahwa Efektivitas dan efisiensi dari pengendalian internal berkaitan dengan upaya pengamanan dan pengelolaan aset

Dengan demikian, semua hal diatas dapat mendukung hasil dari penelitian ini yang mengungkapakan bahwa implementasi pengendalian internal berpengaruh positif dan signifikan terhadap efektivitas manajemen aset tetap pada perguruan tinngi berbadan hukum di Indonesia.

\subsubsection{Pengaruh Kompetensi Pengelola terhadap Pendeteksian Efektivitas} Manajemen Aset Tetap, pada Perguruan Tinggi Berbadan Hukum di Indonesia.

Berdasarkan hasil uji statistik dapat disimpulkan bahwa Kompetensi Pengelola berpengaruh positif dan siginifikan terhadap pendeteksian Efektivitas Manajemen Aset Tetap, yang artinya semakin baik Kompetensi Pengelola maka akan semakin baik pula Efektivitas Manajemen Aset Tetap. Pengkuruan terhadap kompetensi pengelola dalam suatu organisasi adalah hal penting, hal ini bertujuan untuk mengetahui kompetensi pegawai saat ini; mengidentifikasi kesenjangan antara deskripsi pekerjaan kompetensi mereka dan dapat menentukan aspek penting bagi rencana pembangunan untuk mencapai kompetensi masa depan yang diperlukan untuk tugas-tugas pekerjaan yang akan dilakukan. Hal ini dapat mencegah serta menanggulangi kecurangan-kecurangan yang mungkin terjadi di instansi serta dapat mengetahui dan meminimalisir risiko-risiko yang akan dihadapi dalam pengelolaan aset, dengan demikian hal ini juga akan meningkatkan efisiensi dan efektivitas dari kegiatan operasional instansi, termasuk didalamnya adalah efektivitas manajemen asset.

Hasil penelitin ini senada dengan penelitian sebelumnya yang mengatakan bahwa kompetensi auditor internal berpengaruh positif dan siginifikan terhadap kesehatan finansial bank umum syariah. Hal tersebut dikemukakan oleh Hastings (2010) pengelolaan manajemen aset membutuhkan kompetensi sumber daya manusia yang sesuai dengan tugas, termasuk pengetahuan yang sesuai, keterampilan, pengalaman, perilaku, sikap, dan sifat. Diaswati Mardiasmo, et al. (2011) mengungkapkan bahwa manajer pengelolaan aset harus berupaya untuk memastikan profesionalisme sumber dayanya dalam praktek manajemen aset.

Berdasarkan penelitian yang dilakukan Peach (2014) di University of Queensland Knowledge dan skill staff meningkat semenjak diberlakukan sistem baru dalam pengelolaan manajemen aset. Hal ini senada dengan penelitian yang dilakukan Mita Arlini et.al (2016) yang menyatakan bahwa, sumber daya manusia harus memiliki pengetahuan, keterampilan yang baik dalam pelaksanaan manajemen aset, akuntabilitas publik, monitoring dan evaluasi, dan efektivitas pengelolaan aset yang diselenggarakan untuk mencapai laporan aset yang baik.

Penelitian yang dilakukan Grubisic (2009), Efektivitas Manajemen Aset Publik diukur dari klasifikasi aset publik, pengakuan aset publik, pengukuran aset publik dan profesionalisme dalam pengelolaan aset publik. Sementara itu Klett (2011) juga merekomendasikan perlunya pelatihan secara berkesinambungan demi pengembangan sumber daya manusia guna menambah knowledge dan skill bagi para pengelola aset dan kompetensi sumber daya manusia merupakan kemampuan untuk melaksanakan fungsi-fungsi untuk mencapai tujuannya secara efektif dan efisien.

Dengan demikian, semua hal diatas dapat mendukung hasil dari penelitian ini yang mengungkapakan bahwa kompetensi pengelola berpengaruh positif dan signifikan terhadap Efektivitas Manajemen Aset Tetap pada perguruan tinggi berbadan hukum di Indonesia.

\subsubsection{Pengaruh Implementasi Pengendalian Internal dan Kompetensi Pengelola Internal Terhadap Efektivitas Manajemen Aset Tetap, pada Perguruan Tinggi Berbadan Hukum di Indonesia.}


Berdasarkan hasil uji statistik dapat disimpulkan bahwa kedua variabel bebas yakni Implementasi Pengendalian Internal dan Kompetensi Pengelola berpengaruh signifikan terhadap Efektivitas Manajemen Aset Tetap, pada Perguruan Tinggi Berbadan Hukum di Indonesia. Hal ini berarti bahwa Pengendalian Internal dan Kompetensi Pengelola secara simultan mampu mempengaruhi Efektivitas Manajemen Aset Tetap.

Variabel yang paling dominan pengaruhnya adalah Implementasi Pengendalian Internal (X1) Hal ini dapat dilihat dari nilai $\beta$ yang tinggi dari variabel lainnya. Pengendalian internal membantu organisasi mencapai tujuannya melalui pendekatan yang sistematik yang dapat dilakukan oleh instansi agar tercipta suatu bentuk pengendalian yang optimal dalam mencegah serta menanggulangi kecurangan-kecurangan yang mungkin terjadi di instansi serta dapat mengetahui dan meminimalisir risiko-risiko yang akan dihadapi dalam pengelolaan aset, dengan demikian hal ini juga akan meningkatkan efisiensi dan efektivitas dari kegiatan operasional instansi, termasuk didalamnya adalah efektivitas manajemen asset.

\section{KESIMPULAN DAN SARAN \\ 5.1 Kesimpulan}

Berdasarkan hasil penelitian, kesimpulan yang dapat diambil adalah sebagai berikut:

1. Secara statistik implementasi pengendalian internal berpengaruh positif siginifikan terhadap efektivitas manajemen aset tetap, pada perguruan tinggi berbadan hukum di Indonesia. Ini berarti bahwa semakin baik implementasi pengendalian internal maka semakin baik pula efektivitas manajemen aset tetap.

2. Secara statistik kompetensi pengelola berpengaruh positif siginifikan terhadap efektivitas manajemen aset tetap, pada perguruan tinggi berbadan hukum di Indonesia. Ini berarti bahwa semakin baik kompetensi pengelola maka semakin baik pula efektivitas manajemen aset tetap, pada perguruan tinggi berbadan hukum di Indonesia.

3. Implementasi pengendalian internal dan kompetensi pengelola secara simultan mampu mempengaruhi efektivitas manajemen aset tetap, pada perguruan tinggi berbadan hukum di Indonesia.

\subsection{Saran}

Berdasarkan hasil penelitian, kedua variabel independen yaitu implementasi pengendalian internal dan kompetensi pengelola terbukti mempengaruhi tingkat efektivitas manajemen aset tetap. Hal ini haruslah mampu dipertahankan. Beberapa hal yang dapat dilakukan adalah sebagai berikut :

1. Implementasi pengendalian internal yang sudah baik ini haruslah dipertahankan serta ditingkatkan oleh perguruan tinggi berbadan hukum di Indonesia. Namun yang perlu diperhatikan adalah pada indikator analisis risiko. Ini merupakan hal yang penting, karena analisis risko yang baik, akan membantu manajemen dalam mencegah, serta mengurangi kegagalan yang berdampak negatif bagi manajemen. Manajemen harus menetapkan standar tersendiri serta memastikan sudah sesuai dengan peraturan perundang-undangan yang berlaku terutama dalam hal penentuan perikatan pelelangan pengadaan barang dan jasa, serta dalam hal penetepan rencana anggaran.

2. Pengkuruan terhadap kompetensi pengelola dalam suatu organisasi adalah hal penting, hal ini bertujuan untuk mengetahui kompetensi pegawai saat ini; mengidentifikasi kesenjangan antara deskripsi pekerjaan kompetensi mereka dan dapat menentukan aspek penting bagi rencana pembangunan untuk mencapai kompetensi masa depan yang diperlukan untuk tugas-tugas pekerjaan yang akan dilakukan. Hal ini dapat mencegah serta menanggulangi kecurangan-kecurangan yang mungkin terjadi di instansi serta dapat mengetahui dan meminimalisir risikorisiko yang akan dihadapi dalam pengelolaan aset, dengan demikian hal ini juga akan 
meningkatkan efisiensi dan efektivitas dari kegiatan operasional instansi, termasuk didalamnya adalah efektivitas manajemen asset. Hal lain yang harus dilakukan adalah dengan menciptakan suasana lingkungan kerja yang lebih akrab dan kekeluargaan, agar komunikasi antar rekan kerja bisa berjalan lancar, dan memperkecil terjadinya resiko konflik antar sesama rekan kerja.

3. Pemerintah melalui sistem penganggaran yang dipertanggungjawabkan kepada perguruan tinggi berbadan hukum yang bersangkutan perlu mendukung kemahiran teknologi yang digunakan untuk pengendalin internal, teknologi tidak hanya harus termutahir tapi juga ramah agar mudah dalam proses operasionaliasinya, oleh karena itu program pelatihan harus di persiapkan sebaik mungkin.

\section{REFERENCES}

Anwar, Sanusi. 2011. Metodologi Penelitian Bisnis. Jakarta: Salemba Empat.

Arens, Alvin A., Randal J. Elder, Mark S. Beasley. 2015. "Auditing dan Jasa Assurance Pendekatan Terintegrasi”. Edisi 12. Jakarta: Erlangga.

Commitee Of Sponsoring Organization Of The Tradeway Commision (COSO) Framework 2013.

Dian Puji N. Simatupang, 2016, dalam workshop "UI Sebagai Perguruan Tinggi Negeri Badan Hukum (PTNBH)". (Online): http://www.ui.ac.id/berita/memahami-pentingnya-sistempengelolaan-aset-di-ptnbh.html. Diakses tanggal 10 Februari 2017

Diaswati Mardiasmo et al.2011. Charles Sampford dan Paul Barnes. "The Exemplification of Governance Principles within State Asset Management Laws and Policies: The Case of Indonesia, Research Journal for Engineering Asset Management and Infrastucture Sustainability, Vol 3 No 5, page 613-631. Publisher: Springer-Verlag London Limited.

Gibson, James L et al. 2009. "Organizations (Behaviour Structure, Process)" Thirteen Edition, McGrow Hill

Grubisic et al, 2009, "Towards Efficient Public Sector Asset Management"; Journal of Financial Theory and Practice Comparative International Governmental Accounting Research Vol 4 No 1 page 145-153, Publisher :Emerald, http://dx.doi.org/ 10.1108/ 10441654986543778

Hariyono.2007, "Modul Diklat Teknis Manajemen Aset Daerah"

Hastings, Nicholas A.J. 2010. "Physical Asset Management". Melbourne: Springer.

Hiro Tugiman. 2013. Pengenalan Audit Internal, Yayasan Pendidikan Audit Internal.

Imam Ghozali, 2013. "Aplikasi Analisis Multivariat dengan Program IBM SPSS Edisi 7", Semarang : Universitas Diponegoro,

Indra Bastian, 2014, “Audit Sektor Publik: Pemeriksaan Pertanggungjawaban Pemerintah", Edisi 3, Jakarta : Salemba Empat

International Professional Practice Framework (IPPF) 2015

Jamal Wiwoho, 2017, "Kebijakan Pengawasan Intern tahun 2017 di lingkungan Kemenristek dikti”.(Online):http://itjen.ristekdikti.go.id/wp-content/uploads/2017/02/Kebijakan-

Pengawasan-Intern-tahun-2017-di-Lingkungan-Kemenristekdikti-oleh-InspekturJenderal.pdf

Japhet,Amos, Nelson Jagero, 2011, "The Levels of Factors that Contribute towards Efficiency, Effectiveness and Strength of the Internal Control Systems (ICSs) With Regard to Noncurrent Assets Safeguard and Management in Public Institutions in Tanzania". International Journal of Academic Research in Business and Social Sciences, Vol. 1, No. 3 page 234-246 ISSN: 2222-6990

Klett.2011. "The Design of a Sustainable Competency-Based Human Resources Management A Holistic Approach", Knowledge Management \& E-Learning: An International Journal, Vol.2, No.3 page 567-578. Publisher : Emerald 
Laporan Hasil Pemeriksaan BPK terhadap penyajian dan pengungkapan Aset Pemerintah pada PTNBH dalam LKPP Tahun 2015

Mahmudi.2015. Manajemen Kinerja Sektor Publik. Akademi Manajemen Perusahaan YKPN. Mardiasmo. 2009. Akuntansi Sektor Publik, Yogyakarta: ANDI.

Mita Arlini et.al.2014. "Pengaruh Kompetensi Sumber Daya Manusia, Sistem Informasi, Regulasi, Dan Kompensasi Terhadap Manajemen Aset", Jurnal Magister Akuntansi Universitas Syiah Kuala Banda Aceh Vol 4 No 3 hal 1145-1156, ISSN 2302-0264

Moh Nazir, 2011. "Metode Penelitian. Cetakan 6". Bogor: Penerbit Ghalia Indonesia. Muchtar Hidayat.2012. Manajemen Aset (Privat dan Publik), Yogyakarta: Laksbang Pressindo Mulyadi, 2014. "Audit 1, Edisi ke-6". Jakarta:Salemba Empat

Faiz.2015." Evaluasi implementasi sistem pengendalian internal : Studi kasus pada perguruan tinggi negeri”. Jurnal Akuntansi Multiparadigma Vol 6 No 1 hal 1-174, ISSN 2086-7603 Universitas Gadjah Mada.

Peach,David Povey, 2013,"Understanding and implementing strategic asset management at the University of Southern Queensland", Facilities, Journal of Facilities Management Vol. 31 No 8 page. 343 - 356, Publisher : Emerald, http://dx.doi.org/10.1108/026327713 11317484

Peraturan Pemerintah Republik Indonesia Nomor 26 Tahun 2015 Tentang Bentuk Dan Mekanisme Pendanaan Perguruan Tinggi Negeri Badan Hukum

Peraturan Pemerintah Republik Indonesia Nomor 4 tahun 2014 mengenai penyelenggaraan pendidikan tinggi dan pengelolaan perguruan tinggi

Peraturan Pemerintah Nomor 60 Tahun 2008 tentang Sistem Pengendalian Intern Pemerintah

Rendon and Rendon.2016." Procurement Fraud in the U.S Department of Defense : Implications for contracting processes and internal controls". Managerial Auditing Journal Vol 13 No 6 page 567-578.Publisher: Elsevier

Robins, Stephen P dan Timothy A Judge. 2015. Perilaku Organisasi. Jakarta: Salemba Empat.

Roe, Robert. A., Taillieu, T.C.B. \& Costa, A.C.2003. "Trust implications for performance and effectiveness". European Journal of Work \& Organizational Psychology Vol 10 No. 3 Page 225-244

Sabirin, Yayu Nurhayati Sri. 2019. Pengaruh Locus of Control, Integritas Auditor, Dan Gaya Kepemimpinan Terhadap Kinerja Auditor Studi Kasus Pada Kantor Akuntan Publik di Kota Bandung. Jurnal Akuntansi Dewantara. VOL. 3 NO. 1 APRIL 2019.

Sekaran, Uma dan Bougie, Roger.2013. Research Method for Business.United Kingdom:John Wiley\&Sons Ltd

Shabrina, 2014, "Efektivitas Pengamanan Aset dalam mewujudkan akuntabilitas di pemerintah kota Surabaya", Jurnal Kebijakan dan Manajemen Publik Universitas Airlangga Vol 2 No.1 hal 876-887, ISSN 2303-3417

Sofo, Fransesco. 2003, "Pengembangan Sumber Daya Manusia", Edisi Pertama, Penerbit: Airlangga University Press, Surabaya.

Sudarmanto, 2009, "Kinerja dan Pengembangan Kompetensi SDM. Yogyakarta: Pustaka Pelajar.

Suharsimi Arikunto. 2010. "Prosedur penelitian : Suatu Pendekatan Praktik. (Edisi Revisi)". Jakarta : Rineka Cipta

Suroso.2014.(Online):http://www.bppk.kemenkeu.go.id/publikasi/artikel/149artikelkekayaan -negara-dan-perimbangan-keuangan/20086-pentingnya-manajemenaset-negara diakses pada tanggal 15 Februari 2017

Sugiyono. 2013. "Metode Penelitian Kuantitatif Kualitatif dan R \& D". Bandung : Alfabeta

The Australian Aset Management Collaborative Group's - AAMCoG, "Pedoman Sistem Terpadu Pengelolaan Aset yang Strategis" | Version 1.0 | 7 December 2012, ISBN: 978-09874699-1-5 
JAAKFE

Vol.10, No.2 Des 2020, hal 25-43

Sabirin, Syarbini Ikhsan

Triwib.2009.Pengendalian Internal atas Pengelolaan aset Negara, (Online): https://www.djkn.kemenkeu.go.id/artikel/detail/pengendalian-intern-atas-pengelolaanaset-negara, diakses pada tanggal 28 Februari 2017

Umi Narimawati.2008.Metodologi Penelitian Kualitatif dan Kuantitatif Teori dan Aplikasi, Bandung: Agung Media.

Warren, Carl S, James M. Reeve \& Philip E. Fess. 2015. Pengantar Akuntansi. Buku Satu. Edisi 21. Jakarta: Salemba Empat. 